\title{
INTRODUCTION: \\ BELIEF NARRATIVES AND THEIR RESEARCH
}

\section{Reet Hiiemäe}

This special issue of the journal Folklore: Electronic Journal of Folklore is dedicated to belief narratives. The articles in the current issue are based on papers that were presented at two joint conferences that took place simultaneously in Macau (China) on March 23-28, 2015. Both conferences focused on the traditions of the supernatural: the conference under the heading Vernacular Religion, Folk Belief, and Traditions of the Supernatural concentrated on the representations of the supernatural in folklore, whereas the second conference, The Supernatural in Literature and Film, explored more specifically the role of the supernatural in literature and film. The idea of the conferences was to explore scientific theories and analyses regarding the concept of the supernatural and supernatural experiences, and find ways to compare respective data across cultures. The current journal issue offers a selection of articles and case studies that are additionally linked with the topic of belief narratives and narrativity, and investigate it from various angles. As for various reasons some of the initially planned authors could not be published, two other topical articles (authored by Victoria Chervaneva and Vito Carrassi) were added to the original selection. As a separate section, the journal presents a case analysis by Elizabeth Ann Berton-Reilly about an American Estonian woman, offering an example of how supernatural beliefs are integrated into life history narration and identity-building.

Research on supernatural experiences, belief narratives, and vernacular belief in a broader sense has increasingly become a trend not only among folklorists, but also other scientists of the humanities (e.g. theologians, historians, scholars of literature). In earlier folklore research, the term 'folk belief' was mostly applied to peasant groups in culturally homogeneous village societies. In the recent decades the meaning of the term has expanded, covering also urban populations and internet communities, which are similarly important contexts where such traditions of creative cultural production develop and spread. The emphasis in research is not any more on 'folk', but rather on individuals, groups, and communities. As Adam Grydehoj, the main organiser of these two confer- 
ences, pointed out, supernatural phenomena, intertwined with vernacular belief, are a truly global phenomenon, and traditions of the supernatural are equally at home in crowded cities and on distant farmsteads. Additionally, interactions between the media (e.g. films, TV-shows) and belief narratives on global as well as local level have become a relevant research topic.

In theoretical discussions the question has been raised if the term 'belief narrative' is appropriate at all, because especially in the contemporary traditions narrating about supernatural phenomena does not necessarily include believing in them. In the same vein, Willem de Blécourt has expressed the opinion that the concept of belief is unsuitable for academic purposes because it is often hard to determine whether an informant 'believes' in something or not, or is unsure about it, or changes his or her mind in different situations (Blécourt 2012: 9). However, disputing about the reality or non-reality of supernatural phenomena or ways of interpreting them has been one of the key characteristics of belief narratives already in earlier times and this mere fact should not hinder us from using this term. The hope to find out the essence of mysterious phenomena or the truth about supernatural experiences is often the very reason why such narratives are generated and told. Therefore the attention of folklorists who study belief narratives should focus not that much on the question of believing, but rather on the ways how individuals and communities verbalise and communicate their experiences as well as various interpretations and beliefs connected with such experiences. I agree with Lotte Tarkka who stressed in one of her recent papers about word magic that rather than a matter of 'belief', word magic - as well as other folklore connected with belief - is a matter of social interaction and performance practices. Thus, the magical power of the word is intertwined in the intergeneric system of communication and cannot be separated from the other aspects of power and efficacy assigned to words and utterances (cf. Tarkka 2016: 7). On the other hand, Vito Carrassi argues in this issue that some sort of belief is included in any narrative and even in fairy tales one may not conceive the ideas of magic, wonder and, above all, fairy separated from vernacular belief. Yet the attitudes of a narrator towards a tale may vary even in the lifetime of a single individual more than once. Concludingly, I would argue that irrespective of the degree of believing, the ways how individuals verbalise their experiences influence the ways that the world is perceived by the narrators themselves and by surrounding people. Ultimately the narrated representations have the power of gradually shaping social reality, as my own article about the interpretation of non-verbal communication in belief narratives in this issue also exemplifies.

The processes of meaning-making of otherwise unexplainable experiences through narrating are described also in several other articles. Kirsten Marie 
Raahauge points out that nowadays many people continue to experience things that they cannot understand or explain (e.g. weird voices, sensations or visual appearances). She describes in her article, based on her recent fieldwork on haunted houses in Denmark, how people who do not believe in the possibility of supernatural agency struggle to make sense of their experiences, producing vague narratives that refer to possible explanations derived from traditional Danish folklore, but also use elements from entertainment products, such as TV-series on haunting, ghost movies, or advertisements about ghost lore used by owners of castles and manors for tourism-related reasons.

Most of the articles in this volume analyse, among other things, how supernatural ideas are adapted and transformed in new social and cultural settings. Huai Bao in his contribution about Chinese thrillers describes how traditional concepts of mediumship and foretelling find resonance in modern films and work there, in turn, as a trigger for the creative fantasy of the audience and for their new or modified beliefs and rituals. Kaarina Koski's article focuses on continuities and changes in Finnish belief traditions. She points out that modern Finnish people who are confronted with out-of-the-ordinary experiences often seek to interpret their experiences through a scientific or Christian vocabulary. Even though neither the Lutheran Church nor science accept personal supernatural encounters, these two discourses are perceived as culturally legitimate and thus help to retain the experiencer's own normality. Koski also outlines a third interpretative line that involves seeking alternative information from various sources and gradually developing an alternative worldview with spiritual emphasis. She concludes that these new worldviews, drawing on international literature and the Internet, have little in common with preindustrial belief traditions in which the presence of unseen realities was accepted more readily.

Victoria Chervaneva's contribution offers the reader a structural approach to the belief narratives. She describes the system of character nomination in oral demonological narratives about the dead, paying particular attention to the syntagmatic level, i.e. methods of introducing demonic characters and linguistic tools employed for this purpose. Chervaneva also attempts to explain the role that this naming system plays in the organisation of a demonological narrative, and to show the relationships between character references and storyline of the text. The questions of structure and classification are also the topic of Vito Carrassi's article about fairy tales within the historical-cultural context of the Irish tradition. The author concludes that the fairy tale can express a multidimensional worldview and has a potential for a more complex idea of reality than usually depicted in the narrative research. 
Kirsten Møllegaard combines literature and the supernatural in her case study about the rich folklore surrounding the famous writer Edgar Allan Poe. Poe's short and complicated life and mysterious death have fuelled both academic and folkloristic narratives. Møllegaard brings to the reader's notice that academic narratives often analyse Poe's fiction biographically as reflections of his life, such as his impoverishment, alcoholism, and frustrated ambition, yet folk narratives typically focus on dark romantic mysteries, especially his fascination with pale, dying women and death. Møllegaard realises that a comparison between Poe's fiction and contemporary legends surrounding Poe's person offers broader sociological perspectives on the complexity of folklore in urban settings.

I hope that the readers will benefit from the articles in this volume, understanding better the interactions between lived and narrated supernatural experiences, and the inputs and adaptations from films, television, and literature, which influence the ways that they are verbalised and re-narrated. Finally, I am deeply grateful to all the authors for their time and effort in writing their articles for this special journal issue. It became clear already during the conferences that not all research questions regarding supernatural experiences and their reflections in belief narratives can be clearly answered and sometimes there is more than one valid interpretation. Thus, further formal and informal debates and analyses will surely follow on this topic in the form of conversations, conferences, articles, and books. I hope that the current collection of articles provides a good platform for continuing these discussions in the future.

\section{REFERENCES}

Blécourt, Willem de 2012. Belief Narratives and Genre. In: Zoja Karanović \& Willem de Blécourt (eds.) Belief Narrative Genres. Novi Sad: ISFNR, pp. 9-10. Available at http://www.ff.uns.ac.rs/vesti/aktuelno/2011/BNN_zbornik_konacna.pdf, last accessed on June 17, 2016.

Tarkka, Lotte 2016. Words, Powers, and Genres: Notes on the Efficacy of Oral Poetry. Symposium "Word Power", University of Tartu, April 25-27, 2016. Abstracts. Tartu: University of Tartu, pp. 6-7. Available at http://www.ut.ee/folk/files/ word_power_2016_abstracts.pdf, last accessed on July 4, 2016. 